\title{
"Upon the Limits of Rights Regimes": Reception Conditions of Asylum Seekers in the Republic of Ireland
}

\author{
LiAM THORNTON
}

\section{Abstract}

Only in recent years has Ireland had to deal with appreciable numbers of asylum seekers coming to her shores. The reception of asylum seekers awaiting determination of refugee claims has drastically altered in that period. From inclusion to exclusion has been the hallmark of the legal regulation of reception conditions for asylum seekers. Legal protection from the Irish courts in ensuring a degree of socio-economic protection to asylum seekers is unlikely to be forthcoming. Traditional arguments on asylees' rights as being "different" from Irish citizens and those of other residents have been utilized to justify exclusion from the welfare state. Ensuring the reception of asylum seekers within traditional welfare state structures, where their rights and needs are considered in a similar manner to those of citizens, is the underlying argument of this paper.

\section{Résumé}

Ce n'est qu'au cours de ces dernières années que l'Irlande a eu à faire face à un nombre sensible de demandeurs d'asile arrivant sur ses rivages. Durant cette période, l'accueil des demandeurs d'asile en attente de la détermination de leurs revendications du statut de réfugié a radicalement changé. Le cadre légal des conditions d'accueil des demandeurs d'asile est passé de l'inclusion à l'exclusion. Il y a très peu de chance de voir les tribunaux irlandais fournir une protection légale aux demandeurs d'asile, ce qui leur assurerait un degré quelconque de protection socio-économique. Les arguments traditionnels selon lesquels les droits des personnes admises à titre d'asile sont " différents" des droits de citoyens irlandais et d'autres résidants, ont été utilisés pour justifier cette exclusion de l'État-providence. L'argumentation sous-jacente de cet article est la nécessité d'assurer l'accueil des demandeurs d'asiles à l'intérieur des structures traditionnelles de l'État-providence, où droits et besoins sont considérés de façon semblable aux citoyens.

\section{Introduction}

The hallmark feature of the Irish reception system for asylum seekers has been the continual withdrawal and diminution of social rights on the grounds of preserving the integrity of immigration controls and protection of the welfare state from those who are viewed as not having a definitive right to be within the country. The Irish reception system separates asylees from mainstream welfare provision. It denies an asylum seeker the right to be self-sufficient. The reception regime insists that the asylee reside in particular locations, away and apart from the host community. The asylum seeker is viewed as neither a citizen nor a warranted class of individual deserving of social rights on par with others in need. The development of a separated social welfare regime for asylum seekers was not inevitable. However, past exclusionary practices towards immigrants may have underpinned Irish Governmental responses to the creation of the current reception conditions for asylum seekers.

This article will first consider European law and international law relating to the reception of asylum seekers and socio-economic rights thereof. After a historical analysis of reception conditions within Ireland, current reception conditions for asylum seekers will be considered. Both the protection offered by the Irish courts and political and societal responses to reception standards and practices will also be examined. 
From a country of mass emigration to a country of net immigration, Ireland only began to experience appreciable asylum flows in the last decade. ${ }^{1}$ Throughout this period there has been a tendency to exclude asylum seekers from supports that are seen as essential to allowing citizens and legal residents to live with a basic degree of dignity. "Reception conditions" refer to those social support conditions in place which are provided to asylum seekers whose claim for refugee status has not yet been determined. These supports range from accommodation, provision of food, and clothing to financial assistance. Further supports include education for children and, in some cases, the right to work or the right to participate in vocational training for adult asylees.

The Irish welfare system, wherein access was once based on the "need" of an individual, must now consider a person's legal status in the country. Asylum seekers, who have authorized presence within Ireland, ${ }^{2}$ have been greatly affected by exclusion from the traditional structures of the welfare state. Justifications have been proffered for a separate welfare system for asylum seekers, on the basis that "[v]oters became concerned that the welfare state should not be a honey pot which attracted the wretched of the earth." ${ }^{3}$ The argument is made that while in the host State an asylum seeker enjoys a standard of living far higher than she would enjoy if she were back in her country of origin. This, it has been argued, attracts asylum seekers from their countries of origin. ${ }^{4}$

Within Ireland, asylum seekers exist as a unique category of immigrant, wherein there are no statutory or constitutional rights to social support. Support is provided on the basis of ministerial circulars, wherein parliamentary scrutiny for the whole system of reception for asylum seekers is absent. Limitations that exist within the reception system for asylum seekers do not sit well with the Irish government's commitments to social inclusion, solidarity, multiculturalism, and anti-racism. ${ }^{5}$ This article considers the legal and political debates which led to the exclusion of asylum seekers from a formerly inclusive social welfare system.

\section{European and International Law}

\section{European Union Law}

The Tampere Conclusions committed the European Union to create "a Common European Asylum System (CEAS), based on the full and inclusive application of the Geneva [Refugee] Convention.” The CEAS was to include inter alia the creation of minimum conditions of reception of asylum seekers. ${ }^{6}$ The legal basis for the EU's actions within the asylum and migration field is located within Title IV of the Treaty Establishing the European Community (TEC). ${ }^{7}$ Due to the difficult nature of negotiations with Denmark, European countries agreed that this country would not be bound by any legal standards of CEAS. In relation to Ireland and the UK, both countries had an option to opt in to CEAS measures. This allows both countries to choose which instruments to adopt under the CEAS. Therefore, there is no compulsion to adopt measures which Ireland or the UK feels to be detrimental to their own interests.

In the field of reception of asylum seekers, the European Union has adopted the Reception Standards Directive. ${ }^{8}$ Ireland did not opt in to this directive. The Reception Standards Directive seeks to ensure that asylees within the EU will have a dignified standard of living for the duration of their asylum claim. ${ }^{9}$ The directive also aims to prevent secondary asylum flows within the Union due to a perception of more generous reception conditions in other EU countries. ${ }^{10}$ The directive sets out a number of very limited and qualified rights which the applicant may be entitled to. The right to maintain family unity within state reception measures, ${ }^{11}$ the right to work after one year if the asylum application has not been considered at first instance, ${ }^{12}$ the right of minors to receive education, ${ }^{13}$ the right to basic health care, ${ }^{14}$ and the right to reception conditions that can sustain an individual adequately ${ }^{15}$ are all provided for in the directive. The directive allows for the reduction or withdrawal of reception conditions in specified circumstances. ${ }^{16}$ There are provisions to provide for more ample reception conditions when dealing with an individual who has a special need. ${ }^{17}$ A process must be in place so that those who are refused reception may challenge that decision in an appeal to a court or tribunal. ${ }^{18}$ The socio-economic rights of asylum seekers under Irish law therefore remain beyond the remit of the Reception Standards Directive.

\section{International Law and Standards}

Ireland is a signatory to many international treaties which directly impact on the rights of asylum seekers. The 1951 Convention relating to the Status of Refugees [Refugee Convention] protects the rights of asylum seekers in a number of respects. ${ }^{19}$ The United Nations High Commission for Refugees (UNHCR) has argued that asylum seekers must be treated on the assumption that they are refugees. ${ }^{20}$ In this regard, those claiming refugee status who are "within the territory of" 21 and/or "lawfully present in" 22 a Member State should be entitled to a number of significant rights. The legal basis for entitlement to these rights is the Refugee Convention itself. ${ }^{23}$ Depending on the rights in question, the level of rights protection need either be on par with that of nationals $^{24}$ or be no less than that accorded to aliens generally. ${ }^{25}$ UNHCR has stated that reception conditions of asylum seekers must acknowledge the "centrality of applicable in- 
ternational human rights law and standards in the development and implementation of reception policies." 26 The maintenance of human dignity and self-sufficiency should be the core aims of reception conditions. ${ }^{27}$ Asylees should have access to their basic support needs, ${ }^{28}$ which should include support for vulnerable asylum seekers ${ }^{29}$ and which should ensure family unity. ${ }^{30}$

The International Bill of Human Rights ${ }^{31}$ recognizes the vast array of civil, political, economic, social, and cultural rights which humanity possesses. These rights inhere in all individuals "without discrimination of any kind as to race, colour, sex, language, religion, political or other opinion, national or social origin, property, birth or other status." 32 The rights granted within the International Bill of Human Rights inhere in "everyone," ${ }^{33}$ in "every human being," 34 to "all persons," ${ }^{35}$ and "no one" ${ }^{36}$ can be arbitrarily deprived of these rights. The supervising bodies of the civil and political treaty (Human Rights Committee) ${ }^{37}$ and the socio-economic treaty (Committee on Economic, Social and Cultural Rights) ${ }^{38}$ have outlined the significance and applicability of both treaties to non-nationals. ${ }^{39}$ Asylum seekers also enjoy the rights set out in the other main international human rights treaties to which Ireland is a party. ${ }^{40}$

\section{Historical Analysis of Reception Conditions in Ireland}

Introduction

The Irish welfare system is very much influenced by the welfare system of its former colonial ruler, Britain. ${ }^{41}$ Cousins surmises that the other factors which contributed to the overall development of the Irish welfare state were the role of the Catholic Church and the emphasis on family, ${ }^{42}$ the (until recently) underdeveloped nature of the Irish economy, ${ }^{43}$ and the role of the State. ${ }^{44}$ The Irish welfare state is very much influenced by the Beveridge welfare state model. This model advocates three kinds of benefit: social insurance, social assistance, and universal child benefit. ${ }^{45}$

\section{The Early Arrivals}

Ireland had very little experience with catering for asylum seekers and refugees prior to the 1990s. Refugee status determination procedures were only put in place in the latter part of the twentieth century. The State had played a less than honourable role in refugee protection during World War II. ${ }^{46}$ Ireland acceded to the Refugee Convention in 1956 and to the Protocol in 1967.47 Ireland accepted 539 Hungarian refugees in 1956 who had fled following the failed uprising. ${ }^{48}$ At a governmental level an Interdepartmental Conference on Hungarian Refugees ${ }^{49}$ was established to prepare for the hosting of this refugee population. The Irish Red Cross was responsible for seeing to their material needs. Some money was provided and the refugees received free medical attention, clothes, food, and other essential items. ${ }^{50}$ There was severe discontent within the army camp where the refugees were housed, mainly arising from matters to do with resettlement in other countries. One resident of the camp noted,

[w] e were kept in unheatable wooden huts, on unhealthy food without the possibility of schooling...We do not expressly wish you to transfer us to the US or to Canada, but you have promised us life not concentration camps depriving us of work and hope of life." ${ }^{51}$

The reaction of some elected representatives was less than sympathetic to the plight of the Hungarian refugees. Some members of Dáil Eireann (Irish Parliament) felt that the Hungarians would take the jobs of unemployed Irish people. ${ }^{52}$ One Dáil deputy suggested, in response to the hunger strike by the refugees, that the Government take a "firm stand" against the refugees' action. ${ }^{53}$

From 1973 to 1974 a small group of Chilean refugees arrived in the state. There were no apparent refugee status determination procedures. A voluntary group, Committee for Chilean Refugees in Ireland, with the help of religious groups, provided direct support to the refugees for about two years. ${ }^{54}$ The Chileans received local authority accommodation; however, English classes were only provided for in 1977 and then for just two hours. ${ }^{55}$

In 1979 Ireland took in 212 Vietnamese program refugees. ${ }^{56}$ Seventy-five per cent of the Vietnamese refugees who came in 1979 were accommodated in reception centers. The remainder were housed by religious and charitable organizations. ${ }^{57}$ Most expressed satisfaction with their initial reception within Ireland. ${ }^{58}$ The Vietnamese were dispersed and only the most limited of English language support was provided. Vietnamese children were place in mainstream education without additional educational supports. ${ }^{59}$

Ireland took in 455 Bosnian program refugees between 1992 and $1998 .{ }^{60}$ This was the first refugee program, set up, run, and funded by the State. Bosnians were dispersed around the country and accommodated by the local authority. Both the Vietnamese and Bosnian refugees had a right to work. Both groups were also entitled to access social supports under the Irish social welfare law. While Kosovar arrivals ${ }^{61}$ were not granted the status of "program refugee," they were allowed work and received welfare entitlements if they satisfied the same conditions as applicable to Irish nationals. 


\section{Asylum Seekers within the Modern Irish Welfare State}

Formation of the Current Asylum Support System

In 1986 the Commission on Social Welfare stated that any welfare system should have three aims: the abolition of poverty, redistribution of income, and protection of the standard of living of welfare claimants. The Government, agreeing with these aims, stated that policy within welfare provision is to ensure that "no one is left behind and that we achieve the common goal of building a true and inclusive society for all."62 The Governmental policy document Building an Inclusive Society ${ }^{63}$ defines a person as living in poverty if their "income and resources (material, cultural and social) are so inadequate as to preclude them from having a standard of living which is regarded as acceptable by Irish society generally." ${ }^{64}$ Unable to work, ${ }^{65}$ asylees have no option but to rely on State provision for the duration of their asylum claim. ${ }^{66}$

Originally, asylees within Ireland were catered for within traditional welfare state structures. Entitlement was based solely on need. Asylum seekers were accommodated by the Directorate of Asylum Seeker Support (DASS) under the aegis of the Department of Justice, Equality and Law Reform. ${ }^{67}$ Asylum seekers (and dependents) were initially accommodated in an induction centre. The stay in this induction centre would usually last for one week. After this period, the asylum seeker and any dependents would move into the private rented sector. The Health Service Executive (HSE) would provide asylum seekers with supplementary (rent) allowance. ${ }^{68}$ This would substantially cover the cost of renting the property from a private landlord.

Since asylum seekers could not work, or could not seek work, they were not entitled to unemployment assistance. ${ }^{69}$ The asylee, in line with Ireland's then needs-based approach to welfare, was, depending on her circumstances, entitled to a number of social assistance contingency payments including non-contributory state pension, if s/he was over sixty-six years of age $;^{70}$ blind pension $;{ }^{71}$ non-contributory guardian's payment; ${ }^{72}$ one-parent family payment; ${ }^{73}$ carers' allowance ${ }^{74}$ and illness benefit. ${ }^{75}$ All persons with children in the State, regardless of legal status, were entitled to child benefit. ${ }^{76}$ These payments would be conditional on the asylum seeker meeting the requisite compulsory requirements. For example, only an asylum seeker who was blind would have been entitled to blind pension, or a single parent entitled to one-parent family payment, etc. Medical services were (and still are) free of charge to asylum seekers who satisfy a non-discriminatory means test.

Asylum seekers or dependents of asylum seekers of school-going age ${ }^{77}$ are entitled to be educated in a local school. In 1999 the Refugee Legal Service ${ }^{78}$ was set up as an adjunct to the Legal Aid Board and provides, subject to a means test, legal services for an asylum applicant and may represent her at the Refugee Appeals Tribunal for a fee. ${ }^{79}$

If an asylum seeker did not qualify for one of the social assistance payments, she may have been entitled to supplementary welfare allowance. ${ }^{80}$ Supplementary welfare allowance (SWA) is administered by the HSE on behalf of the Department for Social and Family Affairs (DSFA). SWA provides a residual and support role within the overall income maintenance structure. It aims to provide immediate and flexible assistance to those in need who do not qualify for other state schemes. It seeks to ensure a basic minimum income and, for those with low incomes, to provide support to meet their needs on a day-to-day basis or in emergency situations. ${ }^{81}$ Prior to the introduction of the habitual residence condition, SWA was available to "every person in the State whose means are insufficient to meet his needs..." 82 The HSE could also make exceptional needs payments ${ }^{83}$ and urgent need payments ${ }^{84}$ if the circumstances so warranted. Cash is usually provided to meet an individual's need, but in "exceptional circumstances" the HSE or a deciding community welfare officer may provide goods or service in lieu of monetary payment. ${ }^{85}$

\section{Direct Provision}

The legal basis for the system of direct provision and dispersal was Ministerial Circular 04/00, issued by the Department of Social and Family Affairs (DSFA). However, the Reception and Integration Agency (RIA), located within the Department of Justice, Equality and Law Reform (DJELR), were allocated responsibility for the reception of asylum seekers. ${ }^{86}$ This system was introduced on the premise that the "rights of asylum seekers and refugees are different." 87 Under direct provision and dispersal, bed and board accommodation is provided by the Reception and Integration Agency in hostels, guesthouses, and holiday camps around Ireland. A weekly stipend of $€ 19.10$ is paid to each adult and a sum of $€ 9.60$ for each dependent child. Two exceptional needs payments of $€ 100$ are given per year to asylum seekers. These payments are administered by Community Welfare Officers (CWOs) who are employees of the HSE. The level of payment has not changed since 2000.

DSFA Ministerial Circular 05/00 ${ }^{88}$ made a number of exceptions to the general policy of direct provision. Heavily pregnant women, nursing mothers, and families were to be catered for within the traditional welfare state apparatuses. Asylees were still entitled to the contingency welfare payments, i.e. child benefit, blind pension, one-parent family payment, etc. Despite the discretion of CWOs, many refused to increase the _19.10 payment. $^{89}$ In 2003 asylum seekers and those who were in the country illegally were 
legislatively barred from receiving rent supplement. ${ }^{90}$ This prevented CWOs from placing any asylum seeker outside of the direct provision system. DSFA Circular $02 / 03^{91}$ stated that all the needs of asylum seekers, including those with medical or special needs, were now being catered for within the direct provision system. ${ }^{92}$

Asylum seekers are not obliged to accept the offer of direct provision. However, with the introduction of the habitual residence requirement (discussed below), the element of choice has been somewhat removed for those asylum seekers with no other means.

Accommodation centres issue each asylum applicant with a booklet. ${ }^{93}$ This outlines the services provided by the reception centre; the accommodation rules; and the procedures to be adopted in withdrawing the right to access the accommodation centre. The obligations of the accommodation centre include the provision of a safe, hospitable and clean living environment; the obligation to treat the asylee with dignity and respect; provision of meals and school lunches for children; sanitary facilities; and the obligation to ensure all complaints are dealt with in a fair and efficient manner. ${ }^{94}$ In return, asylum seekers are expected to inter alia treat all persons in the centre with respect, to ensure the safety of their children, to keep noise to a minimum, not to engage in criminal behaviour, and to keep their living space clean and tidy. ${ }^{95}$ Asylum seekers must inform the management of the reception centre of any reasons for absences overnight, or where the asylum seeker moves out of the centre permanently. ${ }^{96}$ Part III of the booklet outlines the complaint procedures in place, in relation to the standards of the accommodation centre and behaviour of residents. In circumstances of extreme seriousness, an asylum seeker may be expelled from the direct provision system entirely. ${ }^{97}$

\section{Habitual Residence and Accessing the Welfare State for Asylum Seekers}

Since May 1, 2004, social assistance contingency payments including SWA and child benefit are subject to the "habitual residence" requirement. ${ }^{98}$ It is therefore presumed, until the contrary is proven, that a person is not habitually resident, unless she has been present in Ireland or Common Travel Area ${ }^{99}$ for a continuous period of two years. ${ }^{100}$ There does not have to be a long-term plan to reside in the country. ${ }^{101}$ The 2004 Act was introduced to prevent abuse of the social assistance system by foreign nationals, and the Dáil debates usually referred to those coming from the (then) ten new European Union accession states. ${ }^{102}$ The Minister for Social and Family Affairs, Ms. Mary Coughlan, T.D., stated that the habitual residence requirement was necessary "to safeguard our social welfare system from ... people from other coun- tries who have little or no connection with Ireland." ${ }^{103}$ However, to ensure compliance with European Community law, EU nationals are entitled to a number of "family" payments which consist of child benefit and one-parent family payment. All EU nationals may also be entitled to SWA where they can show that they are in "genuine and effective employment" and satisfy the legislative criteria for grant of SWA. The granting of SWA would also allow an EU national access to supplementary rent allowance.

Those who applied for asylum after May 1, 2004, were very much affected by the habitual residence requirement. The asylum seeker who has a "temporary residence certificate" 104 and has the right to remain in the state pending final determination of her application would find it difficult to prove that her residence is "habitual" for the purposes of accessing social welfare supports. This ensures that asylum seekers are wholly excluded from mainstream social welfare. Instead, asylum seekers are catered for within an exclusive and excluding direct provision system.

\section{Reception of Unaccompanied Minors}

Unaccompanied asylum seekers under the age of eighteen are under the care of the HSE. ${ }^{105}$ The Separated Children Seeking Asylum Service (SCSA) is the grouping within the HSE which caters for the needs of unaccompanied minors. While minors are in the care of the HSE, provisions of the Child Care Act 1991 apply. ${ }^{106}$ The HSE is under an obligation to promote the welfare of children who are not receiving adequate care and attention. ${ }^{107}$ The welfare of the child is the paramount consideration. ${ }^{108}$ The HSE is obliged to do all that they reasonably can to reunite the child with its family, if this is in the best interests of the child. ${ }^{109}$ An unaccompanied minor must be accommodated and maintained by the HSE. ${ }^{110}$ This care can be given in a number of ways, including placement with foster parents, ${ }^{111}$ placement in residential care, ${ }^{112}$ or making such other suitable arrangements as the HSE thinks proper with regard to the circumstances of the case. ${ }^{113}$

\section{Overview of UK Reception System}

The Irish system of reception for asylum seekers was heavily influenced by British models of social support. Unlike Ireland's, the British system is highly legalized and the system of asylum supports has been subjected to parliamentary scrutiny. ${ }^{114}$ Britain has attempted to withdraw all forms of support from asylees on a number of occasions. ${ }^{115}$ Such attempts were met with judicial censure. ${ }^{116}$ In 2000 Britain introduced a policy of asylum seeker dispersal, and provision for needs by way of accommodation and voucher support. Vouchers could be exchanged for goods at select supermarkets, with access to a very limited amount of cash. ${ }^{117}$ The voucher system was eventually phased out in 
2002. A direct provision system, similar to that operated by Ireland, was to be introduced on a limited and pilot basis. ${ }^{118}$ Britain has in place measures for the suspension or discontinuation of asylee support in specified circumstances. ${ }^{119}$ Within the UK unaccompanied minors are entitled to care and protection by virtue of the Children Act 1989. Similar to Ireland, children may be placed within foster care, residential homes, with extended family, and also within independent and semi-independent accommodation.

\section{Irish Law and International Obligations}

In relation to Ireland's obligations under international law, a number of issues arise. Ireland is failing to comply with the exact requirements of Article 18 (self-employment) and Article 26 (right to choose place or residence) of the Refugee Convention. Those asylum seekers who are "lawfully present in" the State are entitled to be treated no less favourably than aliens generally. The Ombudsman for Children has expressed her concerns in relation to Ireland's non-compliance with the Convention on the Rights of the Child. ${ }^{120}$ The only other definitive statement on compliance of Ireland's reception conditions came from the Committee on the Elimination of Racial Discrimination.

The Covenant on the Elimination of All Forms of Racial Discrimination [CERD] provides that the Convention does not apply to "...distinctions, exclusions, restrictions or preferences made by a State Party to this Convention between citizens and non-citizens." ${ }^{121}$ The Committee has, however, noted with concern the policies of dispersal and direct provision within Ireland. States parties to CERD are under an obligation to "take all necessary steps with a view to avoiding negative consequences for individual asylum seekers and to adopt measures promoting their full participation in society." 122 The Committee had previously criticized the United Kingdom for withdrawing certain social services to asylum seekers and expressed the view that "...it is a matter of great concern that most of the affected persons would be persons belonging to ethnic minorities." ${ }^{123}$ In remains to be seen whether the other human rights treaty bodies will comment on Ireland's international obligations in relation to the direct provision system for asylum seekers.

It appears, however, that the Refugee Convention and international human rights law have not been considered within the formation of reception conditions for asylum seekers within Ireland. UNHCR recommendations of ensuring human dignity and self-sufficiency within reception policies have remained unheeded. Since none of treaties mentioned above are incorporated into Irish law, ${ }^{124}$ it is unlikely that the Irish courts will intervene to ensure compliance.

\section{The Courts and Asylum Seekers}

\section{Constitutional Rights and Asylum Seekers}

Ireland's constitution, Bunreacht na hEireann (1937), recognizes "Fundamental Rights" under articles 40 to $44 .{ }^{125}$ In earlier jurisprudence personal rights of individuals were viewed as emanating from the "Christian and democratic nature..." of the State. ${ }^{126}$ Walsh J. in the McGee case stated that "...natural rights or human rights, are not created by law, but that the Constitution affirms their existence and gives them protection." 127 Rights concepts were based on precepts of natural law. This natural law "...is of universal application and applies to all human begins..."128

\section{Socio-economic Rights and the Irish Courts}

Can the Irish constitution assist asylum seekers in preventing exclusion from the traditional structures of the welfare state? Article 45 of the Irish Constitution is entitled "Directive Principles of Social Policy." Article 45 envisages a social order wherein the State protects the welfare "of the whole people." "Justice and charity" inform all the institutions of national life. ${ }^{129}$ However, this provision is for the "general guidance" of the Oireachtas (Parliament and Senate) and is not to be cognizable in any court. ${ }^{130}$ In the case of Ryan $v$. Attorney General ${ }^{131}$ Kenny J. stated:

[w] hen dealing with controversial social, economic and medical matters on which it is notorious views change from generation to generation, the Oireachtas has to reconcile the exercise of personal rights with the claims of the common good and its decision on the reconciliation should prevail unless it was oppressive to all or some of the citizens... ${ }^{132}$

The Irish courts have shown themselves willing to deal with socio-economic issues where specific constitutional rights are at issue, such as the right to education ${ }^{133}$ or the right to private property. ${ }^{134}$ However, it has proven difficult for the Irish courts to develop any jurisprudence on constitutional social rights. In the case of O'Reilly v. Limerick Corporation ${ }^{135}$ Costello J. rejected inter alia the argument that the constitutional rights of dignity and vindication of the person extend to ordering the State to protect socio-economic rights of individuals. ${ }^{136}$ The learned justice utilized Aristotelian divisions of justice into commutative and distributive fields. Costello J. stated that the court cannot decide whether an individual has been deprived of what is his or her due. Although the Constitution "embraces the notion that the nation's wealth should be justly distributed,"137 this is for elected officials to decide, and not the courts. 


\section{Impact on Asylum Seekers}

The issue of asylum seekers, direct provision, and social rights has, as yet, not come before the courts. In the Supreme Court case of T.D. ${ }^{138}$ Murphy J. stated that Ireland has no obligation to provide "any form of socio-economic benefit for any of its citizens, however needy or deserving." 139 In an obiter statement in the Lobe and Osayende decision, Hardiman J. noted that "...the State makes available to [asylum] applicants an elaborate system of legal advice and free legal representation as well as social welfare or direct provision for their needs. All this is as it should be..." ${ }^{140}$ It therefore would seem that like citizens and other residents, asylees could not rely on Irish constitutional provisions in arguing that their reception conditions are insufficient or inadequate.

\section{British Courts and the Reception of Asylum Seekers}

Even before the adoption of the Human Rights Act 1998, the British courts had taken some tentative steps towards protecting the socio-economic rights of asylum seekers. The British courts have, in general, never declared a common law right to a certain minimum standard of living.

The withdrawal of social rights of asylum seekers by means of a statutory instrument was prevented by the Court of Appeal. ${ }^{141}$ However, the effect of this judgement was later reversed by a legislative amendment. ${ }^{142}$ After this withdrawal, the British courts relied on section 21(a) of the National Assistance Act $1948^{143}$ to ensure that illegal immigrants and asylum seekers did not become destitute and received some assistance. ${ }^{144}$ The New Labour government gave asylum seekers limited rights to social support in the Immigration and Asylum Act 1999. Section 21 was amended to exclude those subject to immigration control, including asylum seekers. ${ }^{145}$ The British courts continued to ensure a certain minimum level of socio-economic protection would be available to certain excluded immigrant categories. In Westminster the Law Lords set down the definitive test which applies under the amended section $21 .{ }^{146}$ A person must be in need of care and attention, and this must arise from one or a combination of the following factors: age, illness, disability, or other circumstances. Any such care and attention must not be provided for by any other statute. This excluded able bodied asylum seekers from its ambit.

Section 55 of the Nationality, Immigration and Asylum Act 2002 attempted to withdraw any entitlement to support for those asylum seekers who did not apply for status "as soon as reasonably practicable.” In Limbuela the House of Lords utilized article 3 of the European Convention of $\mathrm{Hu}$ man Rights to ensure that asylees received a certain minimum level of State support so as to prevent destitution. ${ }^{147}$
All the Law Lords emphasized the specifics of the Limbuela case. Asylum seekers who were lawfully in the country were unable to work. Asylees who were new to the UK and unfamiliar with language and legal requirements had to apply for asylum as soon as the Secretary of State found it would have been reasonably practicable to do so. If an asylum seeker failed to apply for asylum "as soon as reasonably practicable," they were denied any form of State support. Those who failed to gain any familial or charitable support were expected to live on the streets without access to food, water, shelter, heat, or clothing. Baroness Hale noted that:

[t]he State has taken the Poor Law policy of "less eligibility" to an extreme which the Poor Law itself did not contemplate, in denying not only all forms of state relief but all forms of self sufficiency, save family and philanthropic aid, to a particular class of people lawfully here. ${ }^{148}$

Ireland has not attempted to withdraw social rights from asylum seekers to the same extent as the UK. The impact of the European Convention on Human Rights ${ }^{149}$ within the Irish courts on issues relating to socio-economic rights of asylum seekers has yet to be tested before Irish courts. It is, however, highly unlikely that the courts would stray from their traditionalist interpretation regarding the non-justiciability of claims to social rights.

\section{Political and Societal Responses to Reception of Asylum Seekers}

\section{Societal Responses}

Ireland has only recently emerged from the pain and tragedy which mass emigration caused to the population, economy, and national psyche. For much of the nineteenth and twentieth centuries, Irish people had constant need to seek sanctuary for political and economic reasons in countries afar. Irish history and culture is supposedly marked by the Judaeo-Christian tradition, where the "welcoming of the stranger...becomes the occasion of blessing and fruitfulness." 150 Saorstát Eireann (The Irish Free State) along with the Republic of Ireland had a shameful history in the treatment of European Jewry and Hungarian political persecutees. Chilean, Bosnian, and Kosovar refugees fared somewhat better.

Rather than recognizing the historical parallels with Ireland's past, the increase in the numbers applying for asylum saw a reactionary response from the popular press. ${ }^{151}$ Ireland was portrayed as "swamped" by "bogus" asylum seekers. Asylum seekers and refugees were classed as rapists ${ }^{152}$ and criminal thugs. ${ }^{153}$ Asylum seekers were seen as responsible for diverting state resources away from the more 
destitute Irish people. ${ }^{154}$ Asylum seekers were dehumanized $^{155}$ and rumours about their wealth increased. Popular myths among the public included beliefs that asylum seekers were receiving social welfare payments to purchase cars, designer clothes, and mobile phones and for socialization in pubs. ${ }^{156}$ So widespread were the rumours, UNHCR and the National Consultative Committee on Racism and Interculturalism (NCCRI) held an information campaign and produced leaflets which were widely distributed to inform the Irish public on the true nature of the reception system for asylum seekers within Ireland. ${ }^{157}$

\section{Political Responses}

The reaction to the increase in asylum seekers was met with puzzlement and despair by the then Minister for Justice, Mr. John O'Donoghue. The Minister expressed surprise at the level of applications due to a lack of conflict near Irish borders. The fact that Ireland was not a colonial power further added to the surprise in the rise of asylum applications. ${ }^{158}$ Direct provision was justified on the basis of maintaining a Common Travel Area with the UK. The then Minister for Justice also cited the introduction of a new social support scheme for asylum seekers within Britain as a further reason for the introduction of direct provision within Ireland. ${ }^{159}$ This seemed to suggest a perception that there would be further asylum flows to Ireland, were measures not taken to greatly limit and reduce support to those who applied for asylum.

The system of direct provision within Ireland was promoted as being a "fair and effective" means of meeting the basic needs of asylees. ${ }^{160}$ Those asylum seekers who were "genuine" would, according to the Minister, appreciate that one of the purposes behind direct provision was the prevention of fraud. ${ }^{161}$ This statement suggested that the traditional welfare structures which were in place were being used fraudulently by some asylum seekers. Evidence for this contention was not provided by the Minister.

The British asylum debate proceeded on the basis that a large number of economic migrants were bypassing the immigration system through claiming asylum. ${ }^{162}$ The 1998 British White Paper on immigration sought to ensure asylum seekers would not be destitute while their asylum claim was processed. ${ }^{163}$ However, asylum seekers were expected to seek support in their "own communities" before seeking government assistance. ${ }^{164}$ The British Government saw its role as providing a "security net" for those without any other means, on a cashless basis and, as with Ireland, accommodation was provided on a no-choice basis.

The separation of asylum seekers from traditional welfare structures was achieved by the creation of separate welfare bodies. The Reception and Integration Agency
(RIA) within Ireland and the National Asylum Support Service (NASS) within Britain were located within home affairs ministries rather than within social affairs governmental departments. Within both Ireland and Britain, the establishment of these agencies led to an exclusive and isolated welfare system for asylum seekers.

Unaccompanied minors are the one group that remains within legislated social care protection. However, the extent to which unaccompanied minors receive adequate protection has been questioned. The Irish Refugee Council (IRC) has noted the care provided for unaccompanied minors by the HSE is less than adequate. Unaccompanied minors presenting to immigration officials out of hours are often placed in homeless hostels for the first night. There is much less of a care service provided to unaccompanied minors in comparison with Irish children in need of care. The IRC report recommended that a guardian ad litem be appointed to each unaccompanied minor to represent her interests. ${ }^{165}$ The report further recommended a movement away from a hostel type of accommodation, with foster placements to be considered much more readily. ${ }^{166}$

The Ombudsman for Children, Ms. Emily Logan, has criticized the nature of some of the hostel accommodation centres where unaccompanied minors are living. ${ }^{167}$ The standards of these accommodation centres differed greatly, from excellent to less than desirable. ${ }^{168}$ The Ombudsman stated her belief that the differences between care provided to Irish children and that provided to unaccompanied minors breached non-discrimination provisions of the Convention on the Rights of the Child. ${ }^{169}$ Similar concerns have been expressed in relation to the level of care and support which unaccompanied minors received in comparison with other children in the care of the British social services. ${ }^{170}$

\section{Asylum Seekers: From Need to Status within the Irish Welfare State}

The Irish Government deems it acceptable to give asylees a standard of living well below that of others who rely on the "Welfare State." It is Irish governmental policy that all people should live in dignity, where the most vulnerable are "cherished and cared for." ${ }^{171}$ Government policy is to ensure that those relying on the welfare system "can sustain dignity and avoid poverty." 172 However the inclusion of asylum seekers within anti-poverty strategies and social inclusion measures seems superficial.

The welfare state has become a forum for deciding who can be a "full" member of a society, deserving of support, and who may not. ${ }^{173}$ Prior to 2000 , when direct provision was introduced, the Irish welfare system recognized "the essential oneness of humanity." ${ }^{174}$ Need was the main basis for accessing welfare support. Irish discourses on "social 
inclusion," elimination of poverty, full employment, and equality are sparsely applied to the asylum seeker. The involvement of the Irish Justice Department and British Home Office has ensured that asylum seekers' basic needs are treated as lesser than those of others in need. The "oneness" of the poor is separated between the "undeserving" asylee poor and the "deserving" indigenous pauper.

The National Action Plan against Racism 2005-2008 has five key objectives to combating racial discrimination. ${ }^{175}$ The National Action Plan recognizes that racism occurs against labour migrants, refugees, and asylum seekers through overt discrimination, assaults, and other types of behaviour, institutional racism, and labelling. ${ }^{176}$ There is an express commitment to the inclusion of ethnic and racial minorities in tackling poverty and ensuring social inclusion. ${ }^{177}$ However, this is tempered by statements that refugees and asylees are not a "homogenous community"178 in terms of access to rights, services, and integration. ${ }^{179}$ While the National Action Plan notes the harmful effects of discrimination and labelling ${ }^{180}$ it does not fully engage in a discussion on the rationale behind the separation of asylum seekers from the traditional forms of welfare support. ${ }^{181}$

While the Government is committed to developing a more detailed asylum support policy, it will only be done in the framework of direct provision. ${ }^{182}$ Ambiguity remains about the extent to which the system of direct provision can truly avoid a situation wherein an individual can be said to be living free from poverty and living in an inclusive society which fosters interaction, equality of opportunity, and respect.

\section{Challenging the "Welfare Apartheid"}

Within Ireland, asylum seekers live on "the limits of rights regimes." 183 Fanning argues that Irish responses to asylum seekers "have been shaped by a legacy of exclusionary state practices and racism." ${ }^{184}$ Ireland has played a reluctant host to asylees where " $[\mathrm{r}] \mathrm{acism}$ within Irish society continues to be mobilised for administrative purposes." 185 Irish politicians rely on actions of foreign governments as a legitimization for our reception policies towards asylum seekers. The exclusion from the "inclusion debate" marks the asylum seeker as a unique entity within Irish anti-poverty discourses. National welfare states which on their own have been described as being a "threshold of inequality" 186 in and of themselves can, in relation to asylum seekers, be viewed as creating a "new apartheid." 187 Sales notes that changes to the general welfare system have made asylum seekers more visible. ${ }^{188}$ Geddes feels that the "bogus myth of welfare scrounging" 189 is polluting contemporary immigration debate. The separate welfare system and the lack of educational and employment opportunities contribute to the "unde- serving" label applied to asylum seekers. ${ }^{190}$ Moran opines that it is the policies of differentiation of the asylee, through the system of direct provision post-2000, that have sown the seeds of racist and xenophobic reaction of the press and society. ${ }^{191}$ The almost natural exclusion of asylum seekers from traditional welfare state structures is in stark contrast to attempts to foster intercultural debates and to challenge institutionally racist practices.

\section{Conclusion}

State-centric concerns surrounding immigration control and abuse of the asylum system have trumped the ideals of poverty prevention and tackling racial discrimination. Universality and inclusion were at the core of the initial reception system for asylum seekers. However, by 2000, Ireland limited social rights and placed asylum seekers within accommodation centres. Over the years, further restrictions on monetary support were introduced. The de facto exclusion of unaccompanied children who seek asylum from full social care protection is particularly evident when compared to the protection given to Irish children. This further underlines the exclusion of asylum seekers from the welfare state and social care structures. Irish courts have failed to recognize socio-economic rights as inherent within liberal democratic constitutional fundamental rights provisions. This stands in contrast to the approach taken by the British courts. The British courts have placed concepts of human dignity and prevention of inhuman and degrading treatment at the core of social rights protection for asylum seekers. A fundamental re-evaluation of the natural-law-based human rights protection within the Irish Constitution is needed.

Concerns also exist in relation to Ireland's lack of compliance with international law, in particular the Refugee Convention and the various treaties which make up the international human rights treaty regime. While there are a number of flaws within the Reception Standards Directive, had Ireland exercised the opt in, a fully legislated system of asylum support might have been put into place. This would have ensured a number of improvements, in particular regarding the (limited) right to work and a fairer and more transparent system for the complaints of, and against, asylum seekers.

The obstinate response of the press fuelled the perception of asylum seekers as undesirable. The reaction of Irish politicians was not much better. The historical parallel between anti-Irish discrimination in other countries and the discrimination in place for asylum seekers has been ignored. Provision of support and services for asylum seekers through the mainstream welfare state should be the core aim of Government policy. The adoption of a rights-based 
approach to minimum social entitlement for asylum seekers will ensure a more inclusive and participatory democratic society. Such aims would also honour the Irish Government's commitments to poverty prevention, social inclusion, and anti-racism.

\section{Notes}

1. For a breakdown of the Irish statistics on asylum applications, please see online: cf $2<$ http://www.orac.ie/> (date accessed 3 October 2007).

2. Section 8(1)(a) of the Refugee Act 1996 (as amended).

3. Westminster City Council v. National Asylum Support Service, [2002] UKHL 38, para. 20, per Lord Hoffman.

4. Ibid.

5. See Department of Social, Community and Family Affairs, National Anti-Poverty Strategy (Dublin: Stationary Office, 1997); Department of Justice, Equality and Law Reform, Integration: A Two Way Process (Dublin: Stationary Office, 2000), Department of Social, Community and Family Affair , Building an Inclusive Society (Dublin: Stationary Office, 2001), Department of Justice, Equality and Law Reform, National Action Plan against Racism 2005-2008 (Dublin: Stationary Office, 2005), Department of An Taoiseach, Towards 2016: Ten-year Framework Social Partnership Agreement 2006-2015 (Dublin: Stationary Office, 2006), Office of Social Inclusion, National Action Plan for Social Inclusion 2007-2016 (Dublin: Stationary Office, 2007).

6. Paras. 13 and 14 of the Tampere Conclusions.

7. Consolidated Versions of the Treaty of the European Union (TEU) and of the Treaty establishing the European Community (TEC) [2006] Official Journal C.321.E/1.

8. Council Directive 2003/9/EC of 27 January 2003 Laying Down Minimum Standards for the Reception of Asylum Seekers [2003] Official Journal L.31/18. The UK did opt in to this directive and therefore is bound by its terms.

9. Preamble 7 of Reception Standards Directive [RSD]. Under article 4 of the Directive nothing prevents member states from adopting more favourable conditions.

10. Preamble 8RSD.

11. Article 8 of the Directive states that if families are provided with housing, the Member State should "as far as possible" maintain family unity.

12. Under article 11RSD, member states may provide for the right to work at an earlier stage of the asylum process; however, member states may also specify that nationals of member states or other third country nationals should have priority over asylees in gaining access to the labour market.

13. Article 10RSD. However, education may take place in reception centres, or a child's access to education may be delayed for a period of up to one year. In that period, the child should be following a specified education program which would see her accessing mainstream education in the future.

14. The right to health care under article 15RSD may be limited to emergency or essential treatment of illness.
15. Articles 13 and 14 of the Directive set out the rights and entitlements of asylees and the modalities of reception conditions including allowing States a variety of means to implement reception conditions be it by accommodation, cash, or in-kind support.

16. Article 16RSD provides for the withdrawal or reduction of reception conditions where a claim has not been made as soon as reasonably practicable, the asylee abandons his accommodation, has already lodged a claim in another member state, or has sufficient means to support him/herself. Supports must be withdrawn or reduced only after a careful and objective decision is reached on the individual case at hand.

17. Articles 17-20RSD. Unaccompanied minors, minors, pregnant women, victims of torture or sexual abuse, the disabled, and the elderly are all considered as being vulnerable.

18. Article 21RSD.

19. The Convention relating to the Status of Refugees, 28 July 1951, 189 U.N.T.S. [Refugee Convention].

20. UNHCR documents have often noted the need for protection of asylees given that all refugees were also, at one time, asylum seekers. UNHCR, Notes on International Protection (Geneva,: UNHCR, 1993), para. 11. Indeed the definition which UNHCR gives to "asylum" in refugee contexts is quite apt: "Asylum, in the core sense of admission to safety in another country, security against refoulement, and respect for basic human rights, is the heart of international protection. Without asylum, the very survival of the refugee is in jeopardy." (para. 8)

21. Art. 3 (non-discrimination), art. 4 (the right to practise religion and instruct children on religious matters), art. 7(1) (exemption from reciprocity), art.8 (exemption from exceptional measures against the person, property, or interests of the nationals of a foreign State, where the refugee is a national of that State), art. 13 (the right to acquire moveable and immovable property), art. 16(1) (free access to Courts), art. 20 (the right to be included in rationing measures), art. 22 (the right to public elementary education), art. 27 (the right to identity papers), and art. 33 (the prohibition of refoulement).

22. Art. 18 (the right for a refugee to lawfully engage "on his own account" industrial, commercial, agricultural or handicraft self employment), art. 26 (right to choose place of residence and the right to move around freely) and art. 32 (a right not to be expelled except on the grounds of national order or public security).

23. This interpretation is shared by a number of well-established academic authorities. See in particular A. Grahl-Madsen, A Commentary on the Refugee Convention 1951 (Geneva: UNHCR, 1997); J. Hathaway, The Rights of Refugees under International Law (Cambridge: Cambridge University Press, 2005), especially c. 3,4 , and 5.

24. Under arts. $4,14,16,20,22(1), 23,24$, and 29 (fiscal charges and taxes) treatment on these issues must be at least as favourable as that given to nationals.

25. Arts. 7(1), 13, 15, 17, 18, 19, 21, 22(2) (post-primary education), and 26 .

(C) Liam Thornton, 2007. This open-access work is licensed under a Creative Commons Attribution-NonCommercial 4.0 International License, which permits use, reproduction and distribution in any medium for non-commercial purposes, provided the original author(s) are credited and the original publication in Refuge: Canada's Journal on Refugees is cited. 
26. Executive Committee Conclusion No. 93 (LIII) of 2002, preamble, para. 3, UNGA Doc. No. A12 (A/57/12/Add. 1).

27. Ibid. at para. (b)(i).

28. Ibid. at para. (b)(ii)

29. Ibid. at para. (b)(iii)

30. Ibid. at para. (b)(iv).

31. This is the name given to the three main human rights instruments within the UN human rights protection framework: the Universal Declaration of Human Rights [UDHR], GA Res. 217A(III) UN Doc. A/810: the International Covenant on Civil and Political Rights [ICCPR], UN Doc. A/6316 (1966); and International Covenant on Economic Social and Cultural Rights [ICESCR], UN Doc. A/6316 (1966).

32. Art. 2, UDHR; art. 2(1), ICCPR; art. 2(2), ICESCR.

33. Art. 3, 6, 8, 10, 11, 13, 14, 15, and arts. 17-29, UDHR; arts. 9, 16, 18, 19, and 22, ICCPR; arts. 7, 8, 9, 11, 12, 1, and 15, ICESCR.

34. Art. 6, ICCPR.

35. Arts. 10, 14, and 26, ICCPR.

36. Arts. 9, 1, and 15, UDHR; arts. 7, 8, 9, and 15, ICCPR.

37. Art. 28 et. seq., ICCPR.

38. The functions of the Committee originally lay with the Economic and Social Council (ECOSOC); however ECOSOC Resolution 1985/17 assigned this competency to a group of independent experts who examine state compliance under the Covenant.

39. See generally Communication No. 965/2000 Karakurtv. Austria, ICCPR, UN Doc. A/57/40, CCPR/C/74/D/965/2000, Vol. 11304 (4 April 2002); Communication No. 1054/2002 Krizv. Czech Republic UN Doc. CCPR/C/85/D/1054/2002; ICESCR General Comment No. 4, para. 6, "[t]he right to adequate housing applies to everyone and in accordance with article 2(2) not subject to any form of discrimination."; General Comment No. 14 The Right to the Highest Attainable Standard of Health (Article 12) UN Doc. E/C.12/2000/4 (11 August 2000), para. 3, "The right to health is closely related to and dependant on the realization of other human rights including the rights to food, housing, work, education, human dignity, life, non-discrimination, equality and the prohibition against torture."

40. Covenant on the Elimination of All Forms of Racial Discrimination [CERD], UN Doc. A/6014 (1966); International Convention on the Elimination of Discrimination Against Women [CEDAW], UN Doc. A/34/46 (1979); International Convention on the Rights of the Child [CRC], UN Doc. A/44/49 (1989). See in particular General Recommendation No. 30, Discrimination against Non-Citizens, UN Doc. CERD/C/64/Misc.11/ rev.3 (February/March 2004). Hathaway in The Rights of Refugees under International Law, at p. 146, states that there is a need for all the treaty supervisory bodies to reject the notion that differences based on citizenship can in some way be "reasonable."

41. M. Cousins, Explaining the Irish Welfare State: A Historical, Comparative and Political Analysis (Dublin: Edwin Mellen Press, 2005) at 8.
42. Ibid. at 13 .

43. Ibid. at 14 .

44. Ibid. at 15.

45. See M. Cousins, Social Welfare Law (Dublin: Thomson Roundhall, 2002). The Beveridge idea of universal and free health service was never adopted within the Republic of Ireland.

46. See generally D. Keogh, Jews in Twentieth Century Ireland: Refugees, Anti-Semitism and the Holocaust (Cork: Cork University Press, 1998).

47. For a list of signatories and ratifications to both the Refugee Convention and the 1967 Protocol, see online: lang1033 $<$ http://www.unhcr.org/cgi-bin/texis/vtx/protect/opendoc. pdf?tbl=PROTECTION\&id=3b73b0d63 $>$ (date accessed: 3 October 2007).

48. E. Ward, "A Big Show Off of What We Could Do'- Ireland and the Hungarian Refugee Crisis of 1956" (1996) 7 Irish Studies in International Affairs 131-141.

49. Ibid. at 136.

50. Ibid.

51. Ibid. at 138-139. Ward notes that food was served cold, the Hungarian refugees were effectively confined to the camp, education for children was provided for inside the camp and not alongside local children. This, she argues, "exaggerated feelings of being in a ghetto." Most of the refugees resettled in Canada and the camp closed on 15 December 1958. Ward ultimately concludes that this episode was a failure and a "big show off to show what we could do." Deputy McQuillan to Minister Aiken, Dáil Debates vol. 161, col. 630 (2 May 1957).

52. Deputy J. Murphy, Dáil Debates, vol. 161, col. 629 (2 May 1967).

53. Deputy Hillery, Dáil Debates vol. 161, col. 630 (2 May 1967).

54. B. Fanning, Racism and Social Change in the Republic of Ireland (Dublin: Manchester University Press, 2002) at 95.

55. Ibid. at 97 .

56. From 1981 to 2000 the Government granted family reunification to 591 applicants. There were 200 births, 33 deaths, and 147 individuals departed to third countries. See online: $<$ http://www.ria.gov.ie/integration/programme_refugees/vi etnamese_programme/> for full figures (date accessed 3 October 2007).

57. C. O'Regan, Report of a Survey of Vietnamese and Bosnian Refugee Communities in Ireland (Dublin: Refugee Agency, 1998) at 46.

58. Ibid. at 48 .

59. Ibid. at 98 .

60. There were 886 persons admitted to the State for family reunification, while 174 individuals voluntarily repatriated themselves in this period, with just 35 people departing to a third country. See online: <http://www.ria.gov.ie/integration/programme_refugees/bosnian_programme/> for full figures (date accesssed 3 October 2007).

61. In 1999 there was an intake of 1,032 Kosovar refugees. There were 31 applications for family reunification approved, 39 births, and 2 deaths. In contrast with the Vietnamese and 
Bosnian repatriation rates, 956 Kosovar refugees were repatriated, with just 144 remaining in Ireland after 2001.

62. Foreword by An, Taoiseach, Mr. Bertie Ahern T.D., An Tánaiste, Mr. Michael McDowell T.D. and Minister for Social and Family Affairs, Mr. Séamas Brennan, T.D. in National Action Plan for Social Inclusion 2007-2016, at 4 [emphasis added].

63. Supra note.

64. Ibid. at 6.

65. Section 9(4)(b) of the Refugee Act 1996 (as amended). Although generally prevented from working, a concession was made to asylum seekers who were in the country for a period of at least twelve months prior to 27 July 1999. For more information on the limited and unsuccessful nature of this scheme, see B. Fanning et al., Asylum Seekers and the Right to Work in Ireland (Dublin: Irish Refugee Council, 2000).

66. On the other hand, those granted refugee status are entitled to all the same rights as Irish citizens, including the right to work, the right to social welfare on the same basis as nationals, the right to health care, the right to reside in the State, and the right to travel (excluding travel to their country of origin); see s. 3 of the Refugee Act 1996 (as amended).

67. The Directorate of Asylum Seeker Support, which was under the Department of Justice, Equality and Law Reform and the Refugee Agency, under the auspices of the Department of Foreign Affairs, merged in April 2001 to form the Reception and Integration Agency (RIA).

68. This legislative base for this payment is now to be found under part III, c. 9 of the Social Welfare (Consolidation) Act 2005 [the 2005 Act]. It should be noted that the 2005 Consolidation Act includes the "habitual residence" requirement. When discussing the asylum support system prior to 1 May 2004, readers should ignore the habitual residence requirement. The 2005 Consolidation Act (as amended by the Social Welfare Act 2006 and the Social Welfare Law Reform and Pensions Act 2006) simply restates the current law within one statute. The previous consolidation act was the Social Welfare (Consolidation) Act 1993.

69. Section 141 of the 2005 Act. To qualify for unemployment assistance (now renamed jobseeker's allowance, see Schedule One of the Social Welfare Law Reform and Pensions Act 2006) an individual must prove that she is actively seeking work. Since asylees are prevented from working (section 9(4)(b) of the Refugee Act 1996), which if breached could result in a fine and/or up to six months in prison, they would be incapable of entitlement to jobseeker's allowance.

70. Now provided under s. 153 of the 2005 Act.

71. S. 161 of the 2005 Act.

72. S. 163 of the 2005 Act provides an entitlement for all those looking after orphaned children to be entitled to a welfare payment. Guardian payment was originally named orphan's pension (see Schedule One of the Social Welfare Law Reform and Pensions Act 2006).

73. S. 173 of the 2005 Act.

74. S. 180 of the 2005 Act.
75. S. 210 of the 2005 Act. This payment had previously been known as disability benefit (see Schedule One of the Social Welfare Law Reform and Pensions Act 2006).

76. Ss. $219-223$ of the 2005 Act.

77. Art. 42.4 of Bunreacht na hEireann provides that the State shall provide for free primary education. S. 31 of the Education (Welfare) Act 2000 sets the minimum school leaving age at sixteen years.

78. Provisions of this scheme are now set down in Civil Legal Aid (Refugee Appeals Tribunal) Order 2005 (S.I. No. 750 of 2005).

79. A person's income must be below _13,000.The current rates are_6for advice and_29 for representation before the Refugee Appeals Tribunal or the High Court.

80. Chapter 11, Part III of the 1993 Act contained the universalistic clauses; the current SWA requirements are contained within Chapter 9, Part III of the 2005 Act (this includes the habitual residence requirement).

81. See L. Thornton, "Discretion and Law in the British and Irish Social Welfare Systems" [2005] Cork Online Law Review X.

82. Full-time students, those in full-time employment, and persons involved in a trade dispute are not entitled to receive SWA. See ss. 190, 191, and 193 of the 2005 Consolidation Act.

83. Exceptional needs payments (ENP) (s. 201 of the 2005 Act) are paid to cover one-off events, where a person could not reasonably expect to pay from their weekly income. ENP are usually made to those who are in receipt of some other social assistance payment. Examples of when the payment may be given include the purchase of utensils and furniture for a new house, purchase of clothing, and visiting family in hospital or prison.

84. Urgent needs payments (UNP) (s. 202 of the 2005 Act) are paid in times of hardship caused by a fire, flood, or some other natural disaster. This payment is not subject to a "habitual residence" test.

85. Section 200 of the 2005 Consolidation Act.

86. Copy on file with the author.

87. Integration: A Two Way Process, supra note 5 at 50 . Such a distinction continues, in the National Action Plan against Racism 2005-2008, supra note 5 at 66 . The DJELR justified the provision of basic accommodation and living supports for asylum seekers as they made " ... a clear distinction between the integration of refugees and the social supports provided to asylum seekers."

88. Copy on file with author.

89. Supplementary welfare allowance (SWA) is a discretionary payment and is hence governed by administrative law rules regarding exercises of discretion. ACWO must therefore come to their own decision on whether an individual has enough income to meet her needs and must act in a genuinely independent manner, and not come to a decision due to undue pressure, real or perceived, from an outside body. For a more detailed analysis see, Free Legal Advice Centres, Direct Discrimination?An Analysis of the Scheme of Direct Provision in Ireland (Dublin: Printwell Co-op, 2003) at 24-26.

(C) Liam Thornton, 2007. This open-access work is licensed under a Creative Commons Attribution-NonCommercial 4.0 International License, which permits use, reproduction and distribution in any medium for non-commercial purposes, provided the original author(s) are credited and the original publication in Refuge: Canada's Journal on Refugees is cited. 
90. Section 13 of the Social Welfare (Miscellaneous Provisions) Act 2003 inserted section 174(3) and (4) into the Social Welfare (Consolidation) Act 1993 and prevented payment of rent allowance to those unlawfully in the State and also to those who had made an application for refugee status. This section has been replaced by section 198(3) of the 2005 Consolidation Act.

91. This circular replaced circular $05 / 00$ and reflected the legislative changes which occurred in the 2003 Social Welfare (Miscellaneous Provisions) Act 2003. Copy on file with the author.

92. While asylum numbers since 2003 have decreased, the numbers within direct provision accommodation have increased. Please see the table below for last set of full figures available, which are accurate as of April 2005. The RIA was expecting a large decrease in use of direct provision after many asylees staying in accommodation centres were granted residence on the basis of their Irish-born child. See Department of Justice, Equality and Law Reform, Value for Money Report on Asylum and Immigration (Dublin: Stationary Office, 2006).

$\begin{array}{llll}2001 & 4,752 & 2004 & 6,785\end{array}$

$2002 \quad 4,316 \quad 2005 \quad 8,080 \quad$ (up to April 2005) $2003 \quad 5,838$

93. DJELR, Direct Provision Reception amd Accommodation Centre Services, Rules and Procedures (29 September 2005). This booklet is currently undergoing an internal review. Booklet on file with the author.

94. Ibid. at 4 .

95. Ibid. at $5-7$.

96. Ibid. at 6 .

97. Ibid. at 11.

98. Section 17 of the Social Welfare (Miscellaneous Provisions) Act 2004. This is now contained in section 246 of the 2005 Consolidation Act.

99. This refers to the United Kingdom, Northern Ireland, the Channel Islands, and the Isle of Man.

100. The "soft law" Social Welfare 108 Handbook on the Habitual Residence Condition (DSFA, 2004) makes it clear that the question of whether a person is habitually resident or not is for the deciding officer solely. Handbook SW 108 outlines five factors for considering "habitual residence": length and continuity of residence; length and purpose of any absence from a country; the nature and pattern of any employment; the applicant's main centre of interest; and the future intention of the applicant as it appears from all the circumstances. These factors are non-exhaustive and no single factor is more important that the others.

101. Re. J. [1990] 2 AC 562. In Trotter v. Trotter (1992) DLR 554 (Enforcement of an English maintenance judgement in Ontario), a person who had applied for residence, but was still on a visitors permit, was held to have become habitually resident.

102. On 1 May 2004, Cyprus, Czech Republic, Estonia, Hungary, Latvia, Lithuania, Malta, Poland, Slovakia, and Slovenia be- came members of the EU. On 1 January 2007, Romania and Bulgaria also became part of the EU.

103. Ms. Mary Coughlan, T.D., Dáil Debates (10 March 2004). The Minister's statements were highly misleading as European

120. Ombudsman for Children, "Report to the UN Committee on the Rights of the Child" (April 2006). The report may be accessed on the Web site of the Ombudsman, online: $<$ http://www.oco.ie $>$, under the "Policy documents" section. See below where this issue is explored in more depth.

121. Art. 1(2) of CERD.

122. Concluding Observations, Ireland, CERD, UN Doc. CERD/C/IRL/CO/2 (14 April 2005), para. 13.

123. Concluding Observations, United Kingdom of Great Britain and Northern Ireland, CERD, A/51/18 (1996) 35 at para. 235.

124. Ireland operates a dualist legal system and under the Constitution, Bunreacht na hEireann, international agreements must therefore be incorporated into the domestic legal system before an individual can rely on their provisions in an Irish court. See also Siritanu v. Director of Public Prosecutions [2006] IEHC 26. Ms. Justice Elizabeth Dunne confirmed that the Refugee Convention did not form part of Irish law.

125. Under these articles inter alia the right to equality, personal liberty, education, family rights, property rights, freedom of expression, peaceful assembly, etc. are all protected. Limitations on these rights are usually included, generally in the interest of the common good. For a full appreciation of the nature of fundamental rights in Bunreacht na hEireann, see G. Hogan, and G. Whyte, The Irish Constitution, reprint (Dublin: Tottel, 2006).

126. Ryan v. Attorney General [1965] I.R. 294 at 312.

127. McGee v. Attorney General [1974] IR 284 at 318.

128. Northants Co. Council v. A.B.F. [1982] ILRM 164 at 166, per Hamilton J.

129. Art. 45.1, Bunreacht na hEireann.

130. Art. 45 , preambular paragraph, Bunreacht na hEireann.

131. [1965] I.R. 294

132. [1965] I.R. 294 at 312.

133. Art. 42, Bunreacht na hEireann.

134. Art. 43, Bunreacht na hEireann.

135. [1989] ILRM 181. This case centred on the rights of members of the Travelling Community for sanitary and other water services to be provided in a site where the Travellers could place their caravans.

136. Art. 40.3.2 provides, "The State shall, in particular, by its laws protect as best it may from unjust attack and, in the case of injustice done, vindicate the life, person, good name and property rights of every citizen."

137. [1989] ILRM 181 at 195.

138. T.D. v. Ireland [2001] 4 I.R 259.

139. [2001] 4 I.R 259 at 316.

140. Lobe \& Osayende v. Minister for Justice, Equality and Law Reform [2003] 1 I.R. 1 at 128.

(C) Liam Thornton, 2007. This open-access work is licensed under a Creative Commons Attribution-NonCommercial 4.0 International License, which permits use, reproduction and distribution in any medium for non-commercial purposes, provided the original author(s) are credited and the original publication in Refuge: Canada's Journal on Refugees is cited. 
141. R.v. Secretary of State for Social Security (exparte Joint Council for the Welfare of Immigrants), R. v. Secretary of State for Social Security (ex parte B) [1997] 1 W.L.R. 275.

142. Asylum and Immigration Act 1996.

143. S. 21 (1) (a) states that: "A local authority may, with the approval of the Secretary of State and to such extent as he may direct, shall make arrangements for providing :

(a) Residential accommodation for persons aged eighteen or over who by reason of age, illness, disability or any other circumstances are in need of care and attention which is not otherwise available to them..."

144. See generally R. v. Westminster LBC et. al (ex parte M. et al.) (Unreported, Court of Appeal, 17 Feb. 1997).

145. S. 116 of the 1999 Act inserted s. 21(1A) into the 1948 Act. The section states that s. 21 of the 1948 Act does not apply where an asylum seekers' need for care and attention has arisen solely because she is destitute; or because of the physical effects, or anticipated physical effects, of destitution.

146. $R$ (Westminster City Council) v. NASS [2002] UKHL 38. See also R. v. Wandsworth LBC et al. (exparte Bhikha et al.) [2000] 1 WLR 2539 and $R$ (Mani) v. Lambeth LBC Unrep. Court of Appeal 9 July 2003 (Times Law Reports, 23 July 2003).

147. $R$ (Adam, Limbuela \& Tesema) v Secretary of State for the Home Office [2005] UKHL 66.

148. [2005] UKHL 66 at para. 77.

149. The European Convention on Human Rights has been incorporated into Irish law by virtue of the European Convention on Human Rights Act 2003.

150. P. Roe, "Refugees and the Challenge of Horizons: A Theological Interpretation" in T.R. Whelan, ed., The Stranger in Our Midst: Refugees in Ireland: Causes, Experiences and Responses (Dublin: Techman, 2001) at 97.

151. See generally NCCRI/Equality Authority, Media Coverage of Asylum Seekers and Refugees in Ireland (Dublin: NCCRI/Equality Authority, April 2003). All examples below come from this publication. It should be noted that the press paid little attention to the different legal status of "asylum seeker" or "refugee." Applicants for asylum were often referred to as "refugees."

152. "Refugee Rapists on the Rampage" The Irish Daily Star (13 June 1997).

153. "Refugees; Police Act to Smash Gang" Evening Herald (6 June 1997).

154. "Asylum Seekers and Homeless Vie for Shelter, Agency" Irish Times (9 May 1997); "Refugees Get $£ 20$ Million Payments" Evening Herald (6 June 1997).

155. "Refugee Tried to Bite Me to Death" Sunday World (February 2000).

156. "Free Cars for Refugees; Cash Grants Buy BMW's" Irish Daily Mirror (16 December 2002).

157. The most current leaflet in the campaign was produced in 2006 and is accessible online: cf2 <http://www.nccri.ie/pdf/ MythsRefugees-AsylumSeekers.pdf $>$ (date accessed: 3 October 2007).
158. Mr. John O’Donoghue T.D., Minister for Justice, Equality and Law Reform, Dáil Debates, Vol. 488, Col. 737 (10 March 1998). "It is a source of puzzlement to many people that at a time when there are no conflicts taking place near our borders ... when we have no colonial links with countries in which political turmoil is taking place and when the number of claims for refugee status is declining in other European states, the Irish state shows a major increase."

159. Free Legal Advice Centres, Direct Discrimination? An Analysis of the Scheme of Direct Provision in Ireland (Dublin: Printwell Co-op, 2003) at 8, see also the statements of Mr. John O'Donoghue T.D., Minister for Justice, Equality and Law Reform, Dáil Debates, Vol. 528, Col. 300, 12 December 2000.

160. Dáil Debates, Vol. 528, Col. 301, 12 December 2000.

161. Dáil Debates, Vol. 513, Col. 674, 27 January 2000

162. Preface by Right. Hon. Jack Straw M.P., Home Secretary, in Fairer, Faster, Firmer (White Paper on Immigration, 27 July 1998).

163. Ibid. at para. 5.5 .

164. Ibid. at para. 8.17 [emphasis added].

165. Ibid. at 43 .

166. Ibid. at 44 .

167. Ombudsman for Children, "Report to the UN Committee on the Rights of the Child," supra note 120.

168. Ibid. at 36 .

169. Ibid. at 36. The Ombudsman also noted the lack of consultation with the children in the hostels, and, like the IRC report, called for a guardianship system to be put in place for all unaccompanied minors.

170. Given that this article will not be going into detail on the modalities of the British system of reception, for further background and detail see F. Mitchell, "The Social Services Response to Unaccompanied Children in England" (2003) 8 Child and Family Social Work 179-189.

171. Preface by An Taoiseach (Prime Minister), Mr. Bertie Ahern T.D., in Transforming Ireland: A Better Quality of Life for All, National Development Plan 2007-2013 (Dublin: National Development Plan, 2007).

172. Building an Inclusive Society, supra note 5 at 6.

173. A. Bloch, "Asylum and Welfare: Contemporary Debates" (2002) 22, no. 3 Critical Social Policy 393-414.

174. R. Dannreuther, and K. Hutchings, Cosmopolitan Citizenship (London: Macmillan Press, 1999) at 12.

175. See National Action Plan against Racism 2005-2008 at 27. These objectives include effective legal protection against racism, ensuring economic inclusion and equality of opportunity, accommodating diversity in service provision, ensuring anti-racism awareness, and promoting diversity, along with ensuring the full participation of migrants in Irish society.

176. Ibid. at 29 .

177. Ibid. at 31 .

178. Ibid. at 54 .

179. For a governmental appraisal of its direct provision policies and provision of ancillary services to asylees, see ibid. at 68 .

180. National Action Plan against Racism 2005-2008 at 58-60. 
181. The National Action Plan speaks of the need to ensure an "equitable approach" to the provision of services to asylum seekers, ensuring a safe and hospitable reception centre with complaint mechanisms, reasonable accommodation of food preferences and cultural and religious diversity; ibid. at 127.

182. Ibid. at 155 .

183. S. Benhabib, The Rights of Others: Aliens, Residents and Citizens (Cambridge: Cambridge University Press, 2004) at 163.

184. Fanning, supra note 54 at 87.

185. Ibid. at 109.

186. M. Bommes and A. Geddis, Immigration and Welfare: Challenging the Borders of the Welfare State (London: Routledge, $2000)$ at 1.

187. E. Mynott, "From a Shambles to a New Apartheid" in S. Cohen et al., eds., in From Immigration Controls to Welfare Controls (London: Routledge, 2002).

188. R. Sales, "The Deserving and Undeserving? Refugees, Asylum Seekers and Welfare Law" (2002) 22 no. 3 Critical Social Policy $456-478$ at 466.

189. A. Geddes, "Denying Access and Welfare Benefits in the U.K." in M. Bommes and A. Geddes, supra note 186 at 139.
190. Ibid.

191. J. Moran, "Refugees and Social Policy" in S. Quin, P. Kennedy, A. Matthews, and G. Kiely, Contemporary Irish Social Policy (Dublin: University College Dublin Press, 2005) at 270.

Liam Thornton is a PhD Candidate, Centre for Criminal Justice and Human Rights at the Faculty of Law, University College Cork (UCC), Republic of Ireland and an Irish Research Council for Humanities and Social Sciences Scholar (2005-2008). The author wishes to thank Dr. Siobhán Mullally, Co-Director of the Centre for Criminal Justice and Human Rights, Faculty of Law, UCC for comments and insights on earlier drafts. The author also expresses his appreciation for the comments of the anonymous referees. All errors remain those of the author alone. 